\title{
The Effect of Blended Learning on Academic Achievement and Attitudes at Social Studies Courses
}

\author{
Barış Çiftçi \\ Nevsehir Haci Bektas Veli Universty, Nevsehir, TURKEY \\ Education Faculty
}

Received: 18 August 2020 - Accepted: 15 December 2020 - Published Online: 31 December 2020

\begin{abstract}
As a result of scientific and technological developments reflection, improvements on education science moved from teacher centered to student and learning centered system. Learning concept is not only seen a at schools and some learning centers but in all areas and places of life. The aim of this study is to search the achievement and persistency of blended learning method at social studies lesson. With the empirical method used at research, the impact of independent variable examined on experimental group is blended learning method. The independent variable used at control group is face to face learning method. The impact of same dependent variable has been searched on experimental and control group. As a dependent variable the results of social studies academic success test has been searched. For the determined dependent variables, between groups assessment has been applied according to pre-test and post-test scores. The experimental application of the research has been applied to 52 students at $7^{\text {th }}$ grade. 26 students take place from experimental group and 26 students take place from control group. According to the findings, no difference has been found between pre-test scores. According to post test and persistency test a significant difference has been appeared in favor of experimental group which is blended learning method. According to repeated measures analyses results between pre-test and post-test, and between post-test and persistency test; comparison of pre-test and post-test, both effect the student achievement. But according to impact results; the effect of blended learning is larger. According to post-test and persistency score results; it came out that for the persistency of knowledge blended learning is more effective than face to face learning. According to the results of persistency test and final application which is a comparison of blended learning and face to face learning, blended learning group is more effective than face to face learning group. While face to face learning group final application score lessen 12 points, blended learning group score lessen 8 points. It can be confessed that according to the persistency of student achievement, blended learning method is more effective than face to face learning method.
\end{abstract}

Keywords: blended learning, academic achievement, social studies.

\section{Introduction}

Due to reflections of science and technological developments upon the field of education, developments in the field of education have started to be student- and learningcentered than teacher-centered. Learning is seen as a concept that can occur not only in schools and special institutions, but also in every second of life (Reigeluth, 1999).

(C) Authors. Terms and conditions of Creative Commons Attribution 4.0 International (CC BY 4.0) apply. Correspondence: Assit. Prof. Dr. Barış Çiftçi, Nevsehir Haci Bektas Veli Universty, Education Faculty, Nevsehir, TURKEY. E-mail: barisciftci@nevsehir.edu.tr. 
Blended learning is a method of distance education that uses technology (high technology such as television, Internet and low technology such as e-mails by voice and conferences) with traditional teaching and learning (Smiths, 2001).

On the other hand, Horton (2009) defined blended learning as a combination of advantaged aspects of both web-based learning and in-class learning. By blended learning, it is usually meant a use of two or more methods for a need of learning. To define blended learning, it is a use of the most effective ways of learning for achieving learning outcomes for certain purposes (Wilson \& Smilanch, 2004).

Electronic media such as the Internet and web will not take place of face-to-face learning and approaches to teaching as claimed by advocators of e-learning a few years ago. Electronic media have not questioned the existence of a teacher or an educational institution. This media will take place with face-to-face learning approaches (Kerres \& Witt, 2003). In web-based learning, teacher's role cannot be underestimated. As learning has not been possible without teachers for centuries, the role of teachers will be of great significance in further learning processes as well. Drucker (2006) said that teachers who are inspectors and mentors will explore strength of learners and guide them to the success, developing their abilities. Gates (1999) claimed that teachers who create synergy in the classroom, are creative, and who have strong relationships with students will be successful. Moreover, the author argued that the worth and salaries of teachers will get higher thanks to technology.

\subsection{Problem statement}

What is the effect of blended learning in social studies on student performance and retention?

\subsection{Sub-problems}

(1) Is there any difference among students' academic achievement pre-test scores based on group variable?

(2)Is there any difference among students' academic achievement post-test scores based on group variable?

(3) Is there any difference among students' academic achievement retentiontest scores based on group variable?

(4) Is there any difference between social studies achievement pre-test and post-test scores of students both in experimental and control groups?

(5) Is there any difference between social studies achievement post-test and retention-test scores of students both in experimental and control groups?

\section{Material and method}

In this study aimed to explore the effect of blended learning on student performance in social studies, experimental design was used. Common characteristics of experimental designs are as follows: (1) More than one group is used and (2) groups are formed through random sampling. That is why there is a need for the existence of one experimental and one control group.

It can be said that pre-test - post-test control group design is a design frequently used in behavioral sciences that gives statistical power to the study, testing the effect of the 
experimental process on the dependent variable, giving an opportunity of interpreting findings regarding cause-effect relationships (Buyukozturk, 2001).

The independent variable whose effect on the experimental group was blended learning. However, face-to-face learning was initiated in the control group. In both experimental and control groups, effects on the same dependent variable were investigated. As a dependent variable, social studies achievement test results were used. Using pre- and post-test scores regarding the dependent variable, comparisons between groups were made.

The first group of study consisted of 57 seventh graders from Ataturk Elementary School, Afyonkarahisar, Turkey. There were 34 students in the experimental group and 33 students in the control group. However, students who could not take pre-test, post-test and retention-test were excluded from the study. As a result, the experimental group consisted of 26, and the control group comprised 26 students. Students were randomly assigned to both experimental and control groups. Students were not informed of to which group they were belonged to and studies were conducted in both classrooms by usual teachers.

Two hours a week were devoted for this study which lasted in four weeks. Hence, a total of 8 hours were devoted for the whole study. In the experimental group, students were exposed to blended learning. But, they were exposed to face-to-face instruction in the control group. Beforehand, a social studies pre-achievement test was administered to students. Then, post-achievement test was administered. Six weeks after the intervention, achievement test was administered again for retention.

While developing an achievement test, measurement begins with a plan called test plan (Özçelik, 1991; İşman \& Eskicumalı, 2001). The first step to do is to determine the content and then, the items according to the content (Tavşancll, 2006). The content is about a unit or a theme that also highlights objectives and behaviors (Demirel, 2007). The achievement test consisted of 20 multiple-choice, five true-false, five fill-in-the-blank, and two open-ended questions. Each of the two open-ended questions was five points while all the remaining was three points.

To check reliability, there are different techniques and formulas. The ones most frequently used are Kuder-Richardson 20 (KR-20), Kuder-Richardson 21 (KR-21) and Cronbach alpha techniques (Erkuş, 2006). KR-20 is used when item scores are not discrete (1-0) (Atılgan et al., 2006). Correct responses of multiple-choice, true-false and fill-in-the-blank questions were given three points while wrong ones were given zero point. It was found that KR-20 reliability coefficient the achievement test produced was .89, average difficulty .52 , and average discriminatory power 40 .

\section{Results}

below.

The results of the study were presented and interpreted according to each sub-problem

Table 1. Results of experiment and control groups' pre-practice of academic success test

\begin{tabular}{|l|c|c|c|c|c|}
\hline \multicolumn{1}{|c|}{ Group } & $\mathrm{N}$ & $\begin{array}{c}\text { Rank } \\
\text { average }\end{array}$ & $\begin{array}{c}\text { Rank } \\
\text { total }\end{array}$ & $\mathrm{U}$ & $\mathrm{p}$ \\
\hline Experiment & 26 & 25.40 & 660.50 & 309,500 &, 597 \\
\hline Control & 26 & 27.60 & 717.50 & & \\
\hline
\end{tabular}

In Table 1, Mann-Whitney U pre-achievement test results of students exposed to blended learning and face-to-face instruction were presented. According to this, there were 
B. Çiftçi - The Effect of Blended Learning on Academic Achievement and Attitudes at ...

nonsignificant differences between pre-achievement test scores of students in both groups $(\mathrm{U}=309,500, \mathrm{p}>.05)$. The rank averages showed that there are not any significant differences between the experimental and the control group. That is, both groups were similar in terms of achievement in social studies at the outset of the study. This result was useful for the purpose of this study.

Table 2. Results of experiment and control groups' post-practice of academic success test

\begin{tabular}{|l|c|c|c|c|c|}
\hline \multicolumn{1}{|c|}{ Group } & $\mathrm{N}$ & $\begin{array}{c}\text { Rank } \\
\text { average }\end{array}$ & $\begin{array}{c}\text { Rank } \\
\text { total }\end{array}$ & $\mathrm{U}$ & $\mathrm{p}$ \\
\hline Experiment & 26 & 38.46 & 1000 & 27 & \multirow{2}{*}{, 000} \\
\hline Control & 26 & 14.54 & 378 & & \\
\hline
\end{tabular}

In Table 2, Mann-Whitney U post-achievement test results of students exposed to blended learning and face-to-face instruction were presented. According to this, there were significant differences between pre-achievement test scores of students in both groups (U=27, $\mathrm{p}<$.05). The rank averages showed that there are significant differences between the experimental and the control group, in favor of the experimental group exposed to blended learning. That is, blended learning was more effective that face-to-face instruction. A reason for this might be a use of maps, pictures, and videos more than the other ways of learning.

Table 3. Academic success permanency test results of experiment and control groups

\begin{tabular}{|l|c|c|c|c|c|}
\hline \multicolumn{1}{|c|}{ Group } & $\mathrm{N}$ & $\begin{array}{c}\text { Rank } \\
\text { average }\end{array}$ & $\begin{array}{c}\text { Rank } \\
\text { total }\end{array}$ & $\mathrm{U}$ & $\mathrm{p}$ \\
\hline Experiment & 26 & 38.87 & 1010.50 & 16,500 & .000 \\
\hline Control & 26 & 14.13 & 367.50 & & \\
\hline
\end{tabular}

In Table 3, Mann-Whitney $\mathrm{U}$ retention test results of students exposed to blended learning and face-to-face instruction were presented. Results indicated that there are significant differences between the experimental group and the control group $(U=16,500, p<.05)$. To the rank averages, there was a gap between both groups. That is, blended learning was more retentive than face-to-face instruction.

Table 4. Academic success test averages and standard deviation values

\begin{tabular}{|l|c|c|c|c|c|c|}
\hline \multirow{2}{*}{} & \multicolumn{3}{|c|}{ Pre-test } & \multicolumn{3}{c|}{ Post-test } \\
\cline { 2 - 7 } & $\mathrm{N}$ & $X$ & $\mathrm{~S}$ & $\mathrm{~N}$ & $X$ & $\mathrm{~S}$ \\
\hline Experiment & 26 & 19.00 & 3.48 & 26 & 86.96 & 4.82 \\
\hline Control & 26 & 20.03 & 1.28 & 26 & 75.76 & 3.98 \\
\hline
\end{tabular}

As can be seen, students in the experimental group exposed to blended learning earned a mean score of 19.00 before the intervention while 86.96 after the intervention. Besides, students in the control group exposed to face-to-face instruction earned a mean score of 20.03 before the intervention. Also, they earned a mean score of 75.76 after the intervention. Accordingly, both groups earned higher mean scores after the intervention.

Table 5. Academic success test pre-practice and post practice points' ANOVA results

\begin{tabular}{|c|c|c|c|c|c|}
\hline Variance Resource & Square total & Sd & $\begin{array}{l}\text { Square } \\
\text { average }\end{array}$ & $\mathbf{F}$ & $\mathbf{P}$ \\
\hline Among subjects & 1326,652 & 51 & & \multirow[b]{2}{*}{51,040} & \multirow[b]{2}{*}{.000} \\
\hline $\begin{array}{l}\text { Group } \\
\text { Experiment/Control }\end{array}$ & 670,153 & 1 & 670,153 & & \\
\hline
\end{tabular}




\begin{tabular}{|l|c|r|r|r|r|}
\hline Error & 656,499 & 50 & 13,130 & & \\
\hline In subjects & 101088,999 & 52 & & & \\
\hline $\begin{array}{l}\text { Calculation pre-test - } \\
\text { post-test }\end{array}$ & 99448,615 & 1 & 99448,615 & 7443,330 & ,000 \\
\hline Group* calculation & 972,346 & 1 & 972,346 & 72,776 & ,000 \\
\hline Error & 668,038 & 50 & 13,661 & & \\
\hline Total & 102415,6511 & 103 & & & \\
\hline
\end{tabular}

Repeated-measures factors had a significant interaction effect both on achievement and retention in both groups. In light of this, blended learning and face-to-face instruction had also main effects on student performance in social studies. The experimental group exposed to blended learning, gaining more from the achievement test before the intervention, has achieved more than the control group exposed to face-to-face instruction.

Table 6. Academic success test average and standard deviation values

\begin{tabular}{|l|c|c|c|c|c|c|}
\hline \multirow{2}{*}{} & \multicolumn{3}{|c|}{ Pre-test } & \multicolumn{3}{c|}{ Post-test } \\
\cline { 2 - 7 } & $\mathrm{N}$ & $\bar{X}$ & $\mathrm{~S}$ & $\mathrm{~N}$ & $\bar{X}$ & $\mathrm{~S}$ \\
\hline Experiment & 26 & 86.96 & 4.82 & 26 & 77.69 & 4.64 \\
\hline Control & 26 & 75.76 & 3.98 & 26 & 63.07 & 4.69 \\
\hline
\end{tabular}

As can be seen, mean scores of students exposed to blended learning have changed from 86,98 to 77,69 after the practice. Also, mean scores of those exposed to traditional teaching and learning have changed from 75,76 to 63,07 . In both groups, it can be mentioned about a decline in mean scores of students they obtained from the achievement test.

Table 7. Academic success test post-practice and permanency points ANOVA results

\begin{tabular}{|c|c|c|c|c|c|}
\hline Variance resource & Square total & Sd & $\begin{array}{l}\text { Square } \\
\text { averages }\end{array}$ & $\mathbf{F}$ & $\mathbf{P}$ \\
\hline Among subjects & & 51 & & \multirow{3}{*}{119,749} & \multirow{3}{*}{.000} \\
\hline Group Exp./Control & 4329,240 & 1 & 4329,240 & & \\
\hline Error & 1807,635 & 50 & 36,153 & & \\
\hline In subjects & & 52 & & & \\
\hline $\begin{array}{l}\text { Calculation pre/post } \\
\text { test }\end{array}$ & 3135,010 & 1 & 3135,010 & 595,269 & .000 \\
\hline Group* calculation & 76,163 & 1 & 76,163 & 14,462 & .000 \\
\hline Error & 263,327 & 50 & 5,267 & & \\
\hline Total & & 103 & & & \\
\hline
\end{tabular}

Accordingly, two different types of learning have caused significant differences from post-intervention to retention. In other words, both blended learning and face-to-face instruction had an interaction effect on retention which was positively affected by both. However, blended learning was found more retentive than face-to-face instruction when post-test and retention-test scores compared. 


\section{Discussion and conclusions}

Nonsignificant differences were found between pre-achievement test scores of students both in the experimental and the control group. According to this, it can be concluded that both groups were similar in terms of achievement in social studies. This can be regarded as important to understand the effectiveness of an intervention. Results that are in parallel to this study's findings have also been concluded by Akbaba (2009), Yapıcı (2011), and Ünsal (2007).

Post-achievement test scores of students in both groups were found in favor of those exposed to blended learning. Blended learning, compared to face-to-face instruction, is more effective with improving student performance. The reason might be that blended learning is enriched with lots of visuals and supported more with visual content. There have also been studies in parallel to this one. According to Usta (2007), Akyol (2009), and Arıkan (2007), blended learning has significant effect on student performance. A study conducted by Garrison and Kanuka (2004) also supports this finding. Doo, Mitchel, and Virginia (2006) found that blended learning affects student performance positively. This result has also been supported by the related literature (She \& Fisher, 2003; Navarro \& Shoemaker, 2000; Frederickson et al., 2005; Aladejana, 2009; Tuckman, 2002; Boyle et al., 2003; Godfrey \& Gyles, 2003; Cüez, 2006; Pereira et al., 2007). El-Deghaidy and Nouby (2008) found significant differences in favor of pre-service teachers exposed to blended learning according to their post-test achievement scores. However, in the literature, there have also been contradictory studies. Ünsal (2007), Deliağaoğlu (2004), Lesh (2000), and Olapiryakul and Scher (2006) did not found significant differences between experimental and control groups according to post-test scores. Moreover, Matches and Asher (2000), and Demirli (2002) concluded that there were not any significant differences between groups. Achievement levels of groups exposed both to web-based learning and face-to-face learning were found close to each other. Colesca, Dobrica and Alpopi (2009) did also not found any significant difference between experimental and control groups in studies they conducted in 2005 and 2008. Nevertheless, in most of the studies, blended working has been found to be more useful to student performance. It can also be thought that blended learning will contribute student performance in social studies.

Comparing mean retention-test scores of both groups, significant differences were detected in favor of the experimental group. According to students' retention-test results, students in the control group showed a decline in their performance more than those in the experimental group. It has been represented in many studies that students do not forget what they learn by sight and hearing.

The results of repeated-measures analysis of variance showed that methods had a significant interaction effect on student performance in social studies when pre- and post-test scores considered. Yet, blended learning was found more effective than face-to-face instruction. Besides, differences were found significant in favor of the experimental group exposed to blended learning. These findings are also supported by the studies of Şahin (2000) and Gültekin (2006). According to Kert and Tekdal (2004), Taşçı (2006), Demirel (2006), Tutaysalgır (2006), Yekta (2004) and Çelik (2007)'s studies, the experimental group has been more successful in light of post-test results. Altınışık and Orhan's (2002) study showed no significant differences according to analysis of covariance of pre- and post-test results.

According to the results of post-achievement test and retention-test, blended learning was found more effective than face-to-face instruction. While means scores of students exposed to face-to-face instruction had a decline of 12, means scores of those exposed to blended learning had a decrease of 8. It can be said that blended learning method is more retentive than face-to-face instruction. 


\section{Acknowledgements}

This research did not receive any specific grant from funding agencies in the public commercial, or not-for-profit sectors.

The author declares no competing interests.

\section{References}

Akyol, Z. (2009). Examining teaching presence, social presence, cognitive presence, satisfaction and learning in online and blended course contexts. Unpublished Doctoral Thesis. Ankara: Ortadoğu Teknik Üniversitesi.

Aladejena, F. (2009). Blended learning and technology-assisted teaching of biology in Nigerian secondary schools. Special Edition of the World Congress on Engineering and Computer Science (pp. 133-140). San Francisco, USA.

Altinişik, S., \& Orhan, F. (2002). Sosyal bilgiler dersinde çoklu ortamin öğrencilerin akademik başarilari ve derse karşi tutumlari üzerindeki etkisi [The effect of multimedia in social studies course on students' academic achievement and attitudes towards the course]. Hacettepe Üniversitesi Eğitim Fakültesi Dergisi, 23, 41-49.

Boyle, T., Bradley, C., Chalk, P., Jones, R., \& Pickard, P. (2003). Using blended learning to improve student success rates in learning to program. Journal of Educational Media, 28(2-3), 165-178.

Colesca, S. E., Dobrica, L., \& Alpopi, C. (2009). Students outcomes and perceptions in a blended learning format. Metalurgia International, 14(8), 222-229.

Cüez, T. (2006). İlköğretim 8. siniflarda fen bilgisi dersinde web tabanli öğretim desteğinin öğrenci başarisina etkisi [The effect of web-based instruction support on student achievement in primary education 8th grade science lesson], Master Thesis. İzmir: Dokuz Eylül Üniversitesi Eğitim Bilimleri Enstitüsü.

Çelik, E. (2007). Ortaöğretim coğrafya derslerinde bilgisayar destekli animasyon kullaniminin öğrenci başarisina etkisi [The effect of using computer-assisted animation in secondary school geography lessons on student achievement], Unpublished Master's Thesis. Marmara Üniversitesi, Eğitim Bilimleri Enstitüsü.

Delialioğlu, Ö. (2004). Effectiveness of hybrid instruction on certain cognitive and affective learning outcomes in a computer networks course, Doctoral Thesis. Ankara: ODTU Sosyal Bilimler Enstitüsü.

Demirel, A. (2006). Sanat eğitiminde bilgisayar ve çoklu ortam uygulamalari [Computer and multimedia applications in art education], Unpublished Master's Thesis. Selçuk Üniversitesi, Sosyal Bilimler Enstitüsü.

Demirli, C. (2002). Web tabanl ögretimin ögretim teknolojileri ve materyal gelistirme dersinde ögrenci basarısina etkisi (f.ü. teknik egitim fakültesi örnegi) [The effect of web-based instruction on student success in instructional technologies and material development course (technical education faculty example)], Unpublished Master's Thesis. Elazıg: Fırat Üniversitesi Sosyal Bilimler Enstitüsü.

Doo, L, Michael, M., \& Virginia, K. (2006). Online vs. blended learning: Differences in instructional outcomes and learner satisfaction. http://robinwofford.wiki.westga.edu/file/view/EJ842695.pdf.

El-Deghaidy, H., \& Nouby, A. (2008). Effectiveness of a blended e-learning cooperative approach in an egyptian teacher education programme. Computers \& Education, 51, 988-1006. 
B. Çiftçi - The Effect of Blended Learning on Academic Achievement and Attitudes at ...

Frederickson, N., Reed, P., \& Clifford, V. (2005). Evaluating web-supported learning versus lecture-based teaching: Quantitative and qualitative perspectives. Higher Education, 5o, 645-664.

Garrison, D. R., \& Kanuka, H. (2004). Blended learning: Uncovering its transformative potential in higher education. Internet \& Higher Education, 7.

Gültekin, K. (2006). Çoklu ortamin bilgisayar programlama başarisi üzerine etkisi [The effect of multimedia on computer programming success], Unpublished Master's Thesis. Hacettepe Üniversitesi, Fen Bilimleri Enstitüsü.

Kert, S. B., \& Tekdal, M. (2004). Literatürdeki tasarim ilkelerine uygun olarak hazirlanmiş multimedya ders yaziliminin lise düzeyi fizik öğretiminde akademik başariya ve kaliciliğa etkisi [The effect of multimedia course software prepared in accordance with the design principles in the literature on academic achievement and retention in high school physics education]. XIII National Educational Sciences Congress, 6-9 July 2004. Inönü Üniversitesi, Malatya.

Lesh, S. G. (2000). Web-based learning: A Kirkpatrick's multilevel evaluation of effectiveness (Dissertation abstracts online). 1 August 2003, OCLC, http://FirstSearch.oclc.org (taken from database).

Olapiriyakul, K., \& Scher, J. M. (2006). A guide to establishing hybrid learning courses: Employing information technology to create a new learning experience and a case study. Internet and Higher Education, 9, 287-301.

Pereira, J.A., Pleguezuelos, E., Merı', A., Ros, A. M., Carmen, M., Toma's, M., \& Masdeu, C. (2007). Effectiveness of using blended learning strategies for teaching and learning human anatomy. Medical Education, 41, 189-195.

She, H. S., \& Fisher, D. (2003). Web-based e-learning environments in Taiwan: The impact of the online science flash program on students' learning. In M. Swe (Ed.), Technology-rich learning environments (pp. 343-364). Singapore: World Scientific Publishing Company, Incorporated.

Şahin, T. Y. (2000). İlköğretim sosyal bilgiler dersinde çoklu ortamlarin etkililiği [Effectiveness of multimedia in primary education social studies lesson]. Ĕ̆itim Araşttrmaları, 1(1), 68-73.

Taşçi, G. (2006). Biyoloji öğretiminde çoklu ortam uygulamalarinin öğrenme başarisina etkisi [The effect of multimedia applications on learning achievement in biology teaching], Unpublished Master's Thesis. Hacettepe Üniversitesi, Fen Bilimleri Enstitüsü.

Tuckman, B. W. (2002). Evaluating ADAPT: A hybrid instructional model combining web-based and classroom components. Computers and Education, 39, 261-269.

Tutaysalgir, H. (2006). Powerpoint sunu programiyla hazirlanan sosyal bilgiler dersi öğretim materyalinin öğrenci tutum ve performanslarina etkisi [The effect of the social studies lesson teaching material prepared with powerpoint presentation program on student attitudes and performance], Unpublished Master's Thesis. Afyon: Afyon Kocatepe Üniversitesi Sosyal Bilimler Enstitüsü. 